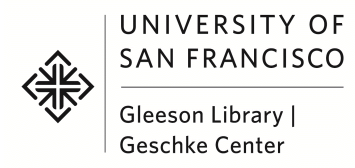

April 2017

\title{
A Conversation with Margaret Atwood
}

Margaret Atwood

Joyce Carol Oates

Follow this and additional works at: http://repository.usfca.edu/ontarioreview Part of the Literature in English, North America Commons

\section{Recommended Citation}

Atwood, Margaret and Oates, Joyce Carol (2017) "A Conversation with Margaret Atwood," Ontario Review: Vol. 9 , Article 3. Available at: http://repository.usfca.edu/ontarioreview/vol9/iss1/3

For more information, please contact southerr@usfca.edu. 


\title{
A Conversation with Margaret Atwood
}

\author{
JOYGE GAROL OATES
}

This interview took place in early February, just before Margaret Atwood left for Paris and Australia and a poetry reading trip in the United States. It was conducted by mail and telephone.

J.C.O.: Your books of poetry - The Circle Game (which was awarded the Governor General's Award in 1966), The Animals in That Country, The Journals of Susanna Moodie, Procedures for Underground, Power Politics, and You Are Happy - differ a great deal in content, yet there is a remarkable similarity of tone, of rhythm, of "texture." Your earlier poems, for instance "Journey to the Interior" and "The Circle Game" itself, show a mastery of craftsmanship that is rather unusual in first books. From whom did you learn, consciously or unconsciously?

M.A.: When I first started writing I was sixteen and in high school, in Toronto, in the fifties, and I knew nothing about either modern poetry or Canadian poetry. So my first influences were Poe and Shelley! When I got to university, I began discovering modern and Canadian poetry, chiefly the latter. I read my way through the library of a faculty member who, being a poet herself, had an extensive collection. I might mention such names as P. K. Page, Margaret Avison, whose Winter Sun I reviewed when I was in university, James Reaney, D. G. Jones, and certain poems of Douglas Le Pan. These poets were important to me not only as poets but as examples of the fact that you could get a book published. You would have to have known the situation in Canada at the time to realize how important this was to me.

It's kind of you to say that you found my first book accomplished, but by the time it came out, I'd been writing for ten years. Also, The Circle Game isn't my real "first book"; there was another one, seven poems long, which appeared in 1961, for which I set the type and designed and printed the cover. I doubt that you would find it quite so unusual!

J.C.O.: Do you enjoy reading your poetry, in general?

M.A.: A good poetry reading is a delightful and exhilarating experience. A bad one is awful. It depends on the audience, on your mood 


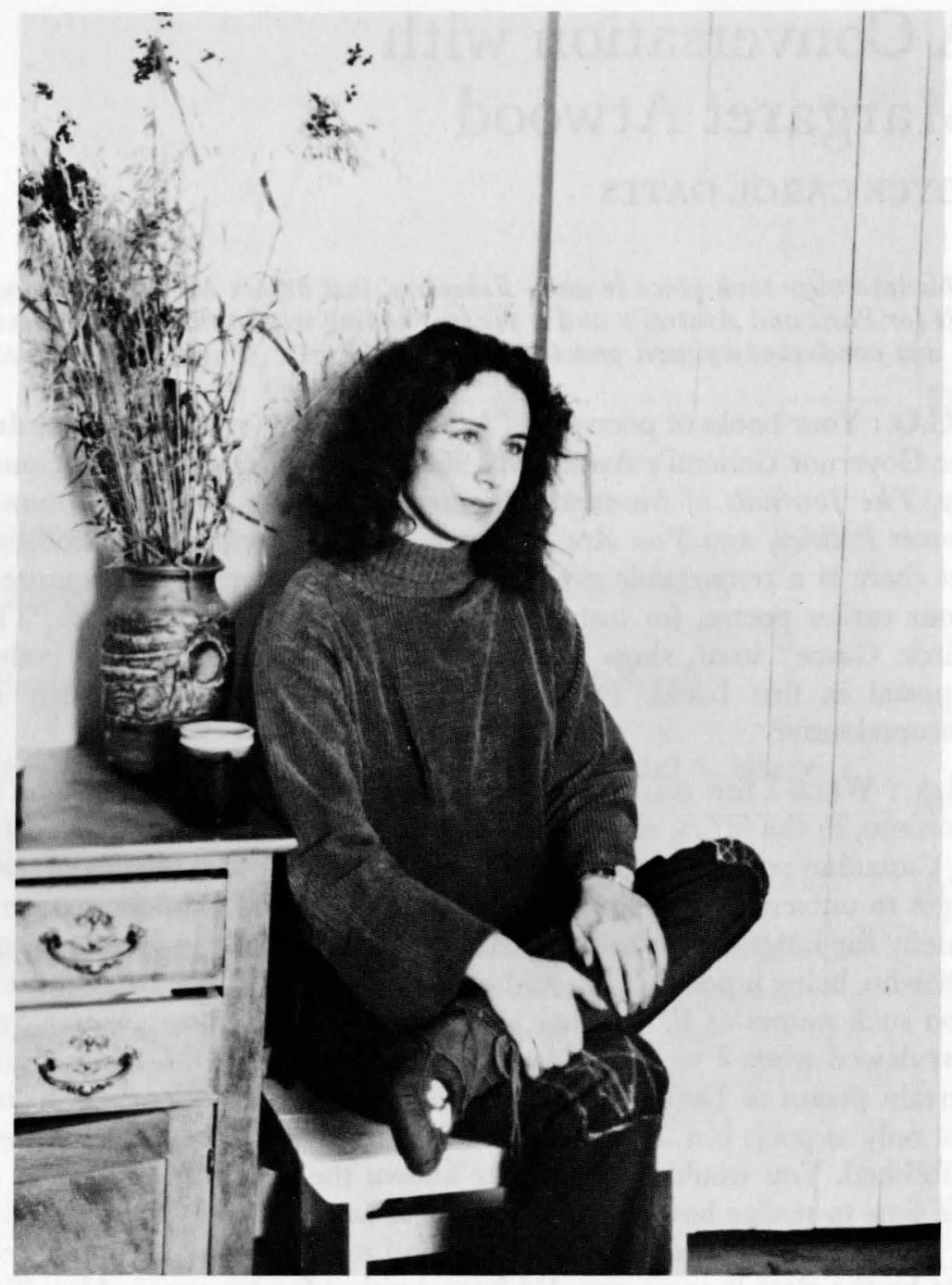

Margaret Atwood

Photo by Graeme Gibson 
at the time, on whether you and the audience "like" each other.... I guess we've all run into the resident madman and the faculty member who thinks he can put a notch in his gun by being gratuitously rude to you at the little luncheon or whatever thrown in your honour.... Mostly I just get colds.

J.C.O.: Your sense of the absurd - and of the essential playfulness of the absurd - is one of the elements in your writing that I particularly admire. What inspired your novel The Edible Woman - especially that surreal final scene - and Lady Oracle?

M.A.: Edible Woman was written in 1965, before the Women's Liberation Movement had begun. It was still very much the model pattern, in Canada anyway, to take a crummy job and then marry to get away from it. I was writing about an object of consumption (namely, my bright but otherwise ordinary girl) in a consumer society. Appropriately, she works for a market research company. Even in 1969 , when the book was finally published, some critics saw the view as essentially "young" or "neurotic." I would mature, they felt, and things (i.e. marriage and kids) would fall into place.

About the cake in the shape of a woman - all I can tell you is that I used to be a very good cake decorator and was often asked to reproduce various objects in pastry and icing. Also, in my walks past pastry stores, I always wondered why people made replicas of things - brides and grooms, for instance, or Mickey Mice - and then ate them. It seems a mysterious thing to do. But for my heroine to make a false image of herself and then consume it was entirely appropriate, given the story - don't you think?

Lady Oracle was written much later - almost ten years later. Again, I'm not sure where it began, but the central character is a writer of Gothic romances partly because I've always wondered what it was about these books that appealed - do so many women think of themselves as menaced on all sides, and of their husbands as potential murderers? And what about that "Mad Wife" left over from Jane Eyre? Are these our secret plots?

The hypothesis of the book, insofar as there is one, is: what happens to someone who lives in the "real" world but does it as though this "other" world is the real one? This may be the plight of many more of us than we care to admit.

J.C.O.: Your novel Surfacing has been related to James Dickey's Deliverance. I see only a superficial, rather misleading relationship. Could you comment? 
M.A.: There is a relationship of sorts, but for me it's one of opposites. For the central figure in Dickey's book, as I recall, nature is something wild, untamed, feminine, dangerous and mysterious, that he must struggle with, confront, conquer, overcome. Doing this involves killing. For me, the books cognate with Dickey's are Mailer's Why We Are in Vietnam, Faulkner's Bear, Hemingway's "Short Happy Life of Francis Macomber," and, if you like, Moby Dick, though Ahab was not seen by Melville as having chosen the right path. The books cognate with mine are Canadian and probably unknown in the United States; Howard O'Hagan's Tay John is one of them.

J.C.O.: "The Man From Mars," which appeared in Ontario Review 6 , is a delightful story, and drew a great deal of favorable comments from our readers. Were your hapless heroine and indefatigable suitor based on "real" people? And is there any political significance to the title?

M.A.: I've found over the years that I can never explain or account for any reader response to my work. It constantly amazes me - and this isn't false modesty - that my work sells as well as it does. I consider it rather quirky and eccentric.

Real people? In a way. The situation was real, the characters are fictional.

The title. . I'm not sure whether the significance is "political" or not; what it means to me is that we all have a way of dehumanizing anything which is strange or exotic to us. In our arrogance, we take ourselves to be the norm, and measure everyone else against it. The man of course is not from Mars; he is from earth, like everyone else. But there's no way of accounting for the atrocities that people perform on other people except by the "Martian" factor, the failure to see one's victims as fully human.

J.C.O.: I believe you're one of the few Canadian writers who is not associated with any university, and I assume this is deliberate.

M.A.: Yes, I enjoyed students when I taught in 1967-68, but I could not handle faculty meetings and departmental politics. I don't understand it. I'm not good in those situations. The reason I don't teach is the same reason I don't wait on tables, which I also used to do: right now I don't have to. If I have to do either again, I will. If it's a choice, I'd take teaching, which is less physically exhausting and doesn't put you off your food so much.

J.C.O.: You have drawn upon your student days at Harvard quite infrequently in your writing. Did you enjoy your stay there? 
M.A.: Well. . Harvard is sort of like anchovies. An acquired taste. But in my case, one that I could never truly acquire, because at that time - early and mid-sixties - they wouldn't let women into Lamont Library, and that was where they kept all the modern poetry and records. So I always felt a little like a sort of wart or wen on the great male academic skin. I felt as if I was there on sufferance. Harvard, you know, didn't hire women to teach in it, so the male professors were all very nice. We ladies were no threat. There was a joke among the woman students that the best way to pass your orals was to stuff a pillow up your dress, because they would all be so terrified of having parturition take place on the Persian rug that they would just ask you your name and give you a pass. One of my female colleagues was almost expelled for dressing like a woman of loose virtue. Actually she was a Latvian Shakespearian scholar with somewhat different ideas of dress than the rest of us tweedy, buttoned types.

So I enjoyed it, yes, in a nervous sort of way. There were some fine lecturers, and Widener Library is wonderful. And little madnesses go on there which seem unlike those of any other place. I often wondered what happened to the man who was rumoured to have broken into Houghton Library (Rare Books) in order to expose himself to the Gutenberg Bible. I do have two "Harvard" stories, which are in Dancing Girls.

The most important things about the experience for me were: it was the place where I first learned urban fear. (Before I went there, I always walked around at night, didn't bother about locked doors, etc. If you behaved that way in Cambridge you were dead.) And, for various reasons, it was the place where I started thinking seriously about Canada as having a shape and a culture of its own. Partly because I was studying the literature of the American Puritans, which was not notable for its purely literary values - if one can study this in a university, I thought, why not Canadian literature? (you must understand that at that time Canadian literature was simply not taught in high schools and universities in Canada) - and partly because Boston was, in certain ways, so similar, in climate and landscape, to parts of Canada. One began to look for differences.

J.C.O.: Did you discover any odd or upsetting attitudes toward Canada while living at Cambridge?

M.A.: It's not that anyone in Boston - few in the Graduate School were from that area in any case; they came from all over the U.S. and from non-North American countries as well - it's not that the Americans I met had any odd or "upsetting" attitudes towards Canada. They 
simply didn't have any attitudes at all. They had a vague idea that such a place existed - it was that blank area north of the map where the bad weather came from - but if they thought about it at all they found it boring. They seemed to want to believe that my father was a Mounted Policeman and that we lived in igloos all year round, and I must admit that after a while I took a certain pleasure in encouraging these beliefs. (Recall that this was before the Vietnam crisis, during which many Americans came to regard Canada as the Great Good Place or game refuge to which they might escape.) I met a number of Southerners and got to know some of them; they seemed to resent "the North" in some of the same ways as did the handful of Canadians there, though for different reasons.

J.C.O.: Why had you gone to Harvard in the first place?

M.A.: Because - to trace it back - Canada had not hired one Jerome H. Buckley back in the Depression when he was looking for work. He had gone to the States and had become a leading Victorianist. The Victorian period was "my period," and I had won a Woodrow Wilson Fellowship, so I went to Harvard to study with Dr. Buckley. There is, you know, a kind of Canadian Mafia at Harvard and elsewhere in the States. Quite a few of the well-known professors at Harvard were closet Canadians. However, they kept their identities secret, for the most part, except when talking with other Canadians. They'd learned by experience that Americans found a revelation of one's Canadian-ness, dropped, for instance, into the middle of a sherry party, about as interesting as the announcement that one had had mashed potatoes for lunch. The beginning of Canadian cultural nationalism was not "Am I really that oppressed?" but "Am I really that boring?" You see, we had never been taught much about our own history or culture - but that's another whole story.

J.C.O.: Is there a very distinctive difference between American "literary" responses and Canadian?

M.A.: I feel that American literary responses are, quite simply, more literary - at least in the groups of people with whom I'm likely to come in contact. I think the difference is that in the States, there is a "literary" culture and a largely non-literary one, whereas in Canada these overlap a great deal more. I'm saying this only on the basis of who is likely to turn up at a poetry reading. But my experience isn't really wide enough to justify such general statements.

I always enjoy going to the States; it's an escape for me, from my own quite demanding culture. People there are polite to me, as they 
would be to a visiting foreigner (which I am), and, though interested, disinterested. Americans have such enthusiasms. It's a change from the gloom here, the suspicion. But of course, Canada is where I really live. That's why I can enjoy the States so much for brief periods of time.

\section{J.C.O.: What sort of working habits have you?}

M.A.: My working habits have changed over the years, according to the circumstances of my life. I started writing seriously - though this may seem ludicrous - when I was sixteen and in fourth year high school. At that time I wrote in the evenings when I was supposed to be doing homework, on weekends and occasionally during school hours. After that, I was in University for four years and wrote between classes, after hours, etc. - a haphazard pattern. I didn't have very regular habits as a student, either; I was a procrastinator and still am, so it helps me to set myself deadlines. (This applies only to prose, of course. Poetry does not get written, by me at least, as a matter of will.) During my years as a graduate student, odd-job-holder, university lecturer of the lowest order - up till the age of about twenty-seven or so - I almost had to write at night, and would stay up quite late. I'm not sure how I wrote at all the first year I spent as a "real" university teacher (1967-68, in Montreal). I was very busy and exhausted, and lost a lot of weight. But I seem to have been writing some then, too. I can't remember when I did it.

I became an afternoon writer when I had afternoons. When I was able to write full time, I used to spend the morning procrastinating and worrying, then plunge into the manuscript in a frenzy of anxiety around 3:00 when it looked as though I might not get anything done. Since the birth of my daughter, I've had to cut down on the procrastination. I still try to spend the afternoons writing, though the preliminary period of anxiety is somewhat shorter. I suppose this is a more efficient use of time. The fact is that blank pages inspire me with terror. What will I put on them? Will it be good enough? Will I have to throw it out? And so forth. I suspect most writers are like this.

J.C.O.: Do you work on more than one project at a time?

M.A.: One project at a time, ideally. I am by nature lazy, sluggish and of low energy. It constantly amazes me that I do anything at all.

J.C.O.: How long, approximately, did it take you to write each of your three novels?

M.A.: I wrote Edible Woman in unused University of British Columbia exam books from April to August of 1965. I revised in the fall. For 
reasons I won't go into, the publisher lost the manuscript, and I was so naive about the process that I thought it normal for them to take two years to tell me anything about it. The book was finally published in 1969. I had written another unpublished novel before this, and wrote another unpublished, unfinished one after it. Then I wrote Surfacing, from about December 1969 to August 1970. There were only minor revisions and some retyping, though the handwritten version was extensively revised. Lady Oracle took much longer, partly because I was living a life filled with more interruptions, partly because it changed a lot while I was writing it. It took about two and one-half years, off and on.

J.C.O.: I've enjoyed the cartoons of yours I've seen. Is drawing another of your talents...?

M.A.: I paint a little and draw, for my own amusement. I've been drawing a political cartoon strip for a Canadian magazine - This Magazine - for some years, under the pseudonym of "Bart Gerrard" (it's nice to get hate mail when they don't even know it's you) and I have a children's book coming out in Canada, in March, for the smallest age group, written, hand-lettered and illustrated by myself. I hesitate to call this a "talent," since I know I'm not very good; that is, I have to rub out a lot in order to get the heads the same size and I have difficulty drawing owls flying sideways.

J.C.O.: You must be disturbed by literary journalists' efforts to categorize you - to package you as "The Reigning Queen of Canadian Literature," or a national prophetess, or even a Medusa. What have your reactions been?

M.A.: I dislike the kinds of titles you mention; I find "Reigning Queen" a particularly offensive one, implying as it does that literature, as practiced by women anyway, is either a monarchy or a beehive. In any case, there's only room for one "reigning queen," who will presumably be stung to death later on when she can't lay any more eggs. Such titles are insulting to the many fine women writers in this country (Marian Engel, Alice Munro, Margaret Laurence, to name three) and threatening to me. Anyone who takes language seriously would never use such a metaphor without being aware of its sinister range of meanings.

I suppose Canada is hungry for a few visible "stars," having been without any for so long. The danger to the writer is early stellification - one may become a vaporous ball of gas. But only if captivated by one's image. Luckily, my image here, as reflected in the press, has not 
been very captivating, at least to me. I can do without "Medusa." (It's one of the hazards of naturally curly hair.)

J.C.O.: Do you think that reviewers and critics have, on the whole, been "fair" to you? Has there been any sort of backlash, as an inevitable consequence of your "rise to fame"?

M.A.: Of course there has been a "backlash"; there always is, but vicious attacks in Canada tend to be much more open and personal than in the United States, partly because of the Celtic, blackly satiric literary tradition and partly because it's much more like a small town. We live in each others' pockets here and the dust and gloom is therefore more intense. There are mixed feelings about small-town boys and girls making good, as you know. On the one hand we're proud of them because they're ours; on the other hand we don't like them getting too big for their boots, so we cut them down whenever possible; on the other hand (Canada, like Kali, has more than two hands), we can't quite believe that one of ours can really be any good - surely it's all some kind of hype or fraud; and on yet another hand, the success of one of our members is a reproach to us. If he could do it, why can't we?

There's that; but also, there have been a number of fair-minded, objectively critical pieces which have dealt genuinely with the shape and characteristics of my work and its strengths and weaknesses. Canadian critics are always more close-mouthed than American ones; they seldom go overboard, and they look with great suspicion upon cult figures, especially their own. This has definite advantages. I think American writers are often made dizzy by a sudden rocket-like stellification, then confused when they are just as enthusiastically banished to outer darkness. Canadian writers are (to put it mildly) seldom permitted to get swelled heads.

J.C.O.: An entire issue of The Malahat Review was devoted to you in Winter 1977. I remember being rather surprised by a photographic essay called "Anima," and wonder what your reactions to it, and to the volume as a whole, were.

M.A.: I also was rather surprised. But then, my capacity to be surprised by other people's reactions to me is, I have discovered, infinite. I don't really see myself as a sort of buttock coming out of an egg (or was it the other way around), and as I recall there were quite a few naked ladies with large breasts. But I think the collage sequence was supposed to have been inspired by my work rather than by my finite personal being, which in this climate is usually swathed in wool. Even so??? 
The truth is that I am not a very glamorous person. Writers aren't, really. All they do is sit around and write, which I suppose is as commendable as sitting around painting your toenails, but will never make it into the fashion magazines. So when I see myself being glamorized or idealized, it makes me squirm somewhat. Of course I'm as vain as most people. I'd rather see a picture of myself looking good than one of myself looking awful. But I've seen so many of both by now, some taken minutes apart. ... A photo is only a view.

J.C.O.: You are a very active member of the Writers' Union of Canada, and along with a delegation of some twelve other writers recently went to Ottawa to protest the importation of American editions of Canadian books. Could you explain the situation? Is it a very serious one? What consequences will follow if the Copyright Act is not modified?

M.A.: There are many writers who are more active than $I$ am at the moment. I was active earlier and hope to be more active later, but having a small child tends to reduce my mobility. However, I do get rolled out like a sort of cannon when heavy guns are required. The Remainders Issue has been one of these occasions.

Briefly, the situation is this. Most English-speaking countries, including the United States, have laws that protect both their writers and their printing and publishing industries against pirated editions and foreign competition. In the U.S., if I understand the law correctly, it is illegal to import any more than a nominal number of books by an American author printed outside the country. That is, a Canadian edition of Allen Ginsberg would be dumped into the Detroit River at the border. (This example is based on an actual case.)

The Canadian law was intended to produce the same result. However, the sloppy wording of the article in question has produced a legal loophole, which was discovered by a Canadian retailer some five years ago. Needless to say, he took immediate advantage of it. He went to the States and bought up remaindered copies of books by Canadian authors originally published by U.S. publishers, imported them into Canada, and sold them at rock-bottom prices, thereby depriving the Canadian publisher of sales and the Canadian author of potential royalties from those sales.

This would not matter much if the book market were not so different in the two countries. The "shelf-life" of a hardback book in the States is ordinarily four to six months. In Canada, it's a year to two years. That is, the book might still be selling briskly in Canada when it's remainder time in the States. The other factor is that - not surprisingly 
- Canadian authors are more popular in Canada as a rule than they are in the States. In other words, the importer knows he has a market. What we are afraid of is that these importers or jobbers will go to the U.S. publishers and encourage them to overprint by agreeing in advance to buy up any surplus.

\section{J.G.O.: Is there any protection for the Canadian author?}

M.A.: The only surefire protection for the Canadian author is to write a contract only with a U.S. publisher, giving him North American rights. If enough authors do this to protect their own royalties, it means the death of the publishing industry in Canada. Partial protection can be obtained by publishing in the States six months later than in Canada. But of course the U.S. publisher would rather publish simultaneously. Note that it is not the U.S. publisher who is doing the "illegal" importing. It's jobbers and Canadian retailers. The U.S. publisher has no control over where remaindered books go once they are out of his hands, so clauses in the contract prohibiting this practice are worthless. I'm told they're also illegal.

A simple change in the wording of one clause of the copyright act would solve our immediate problem. However, we're being told by the Government that the law is all right as it stands - in the face of much evidence to the contrary. We've also been asked what's the matter with us - why do we want to deny cheap books to the Canadian consumer?

J.C.O.: Do you think there are any problems inherent in the fact that so many of the arts are state-supported in Canada? As an American I am impressed with the generosity of the Canadian government, but as a reader and critic I am frequently disturbed by the kinds of publications funded by the Canada Council and the various arts councils. Small presses do not seem to offer much editing advice, with the consequence that books tumble from presses, are "distributed" minimally, and allowed to go out of print almost at once. Without wanting to discourage young writers, I must say that the sheer quantity of hurried and slovenly writing published in Canada is rather demoralizing. (Of course the same thing is rapidly becoming true in the States.) There seems to be no tradition any longer of apprenticeship; student writers are being "published" — or at least printed — and in the long run premature publication will have a deleterious effect on their craft. What is your opinion? - or is this too dangerous an enquiry?

M.A.: This is not at all a dangerous enquiry. There are several different questions here, though, and I will try to deal with them one at a time. 
The Canadian literary scene has been likened (by myself, in fact), to a group of figures dancing with considerable vigour and some grace on the edge of a precipice. The precipice was always there, though it's become more visible recently. I'm referring of course to the Québec situation and the potential splitting-up of Canada. But the group of figures was not always there - not so long ago there were only a few solitary writers who, in the field of fiction anyway, didn't know each other - and they did not always dance, with or without grace and vigour.

To put it more plainly: When I began writing, in the late fifties and early sixties, there were five or so literary magazines in the entire country. The number of books of poetry that came out in a yearincluding small press books and privately printed ones - was under twenty. The new Canadian novels published in a year could usually be counted on the fingers of one hand. Canadian literature was not recognized as a legitimate field of study. Canadian books were not taught in schools. The epithet "Canadian writer" was a term of derision, even to Canadian writers. Almost every writer's ambition was to get out of the country to some place "real" in a literary sense, or at least some place where he could get his books published. Canadian writers were not known in their own country, and even when published were rarely bought or reviewed. (Mordecai Richler's first novel sold 3 copies in Canada. The press run of even a respectable book of poetry was considered good at 200. The publishers of The Circle Game initially printed 450, and were worried that they had done too many. Even now, Canadian paperbacks account for maybe 3 percent of total paperback sales in Canada, and that includes Harlequin Romances.)

We can't take the publishing industry for granted, as one can in the States. It is always tottering on the brink of collapse. We can't take our own existence as writers for granted. True, there has been about a 1,000 percent growth in the publishing industry in the last 20 years, but remember that started from near zero. So what is viewed by an American as "generosity" is seen by us simply as necessity. If the government support that publishers currently receive were to be withdrawn, the industry, by and large, would collapse. The "Canadian Renaissance" in the arts was made possible, in large part, by the Canada Council. None of us like this situation. But none of us want to be back in 1961, either.

Now. . . editing in small presses. As an ex-editor for a small press, Anansi, I have to protest. Editorial time by the bucketful was poured into our books. Our chief editor at that time was Dennis Lee, who is renowned here as an absolutely devoted editor. So it isn't universal. I'd say you get about the same mix as you might in the States: some presses 
serious about the writing, some existing only to get their members and friends into print. I think you see the bad writing here because more of it makes its way across your desk. You couldn't possibly even read all of it that comes out in the States; the sheer volume is so high.

But to me, small presses, good or bad, are a necessity. They're like all those Elizabethan melodramas. Without them, Shakespeare would have had no milieu. They were a place where a writer could, as it were, "try out." Same with "little" magazines. I guess I have a certain belief in the reader, the intelligent reader. I think books will eventually find their own level. This may be overly optimistic.

J.G.O.: I am often annoyed by critics' attempts to reduce complex works of art to simple "thematic" statements. Why are Canadian critics in particular so obsessed with statement and theme at the expense of a thoughtful consideration of technique?

M.A.: I'm probably one of those critics who has annoyed you, since my only critical work, Survival: A Thematic Guide to Canadian Literature, is concerned almost exclusively to demonstrate that there are such things as Canadian themes, which differ either in substance or in emphasis from their counterparts in English and American literature. Would it help if I told you that, even after I had written this book which caused rather a furor here, almost as if I'd said that the Emperor was naked - many critics resolutely continued to deny that there was any such thing as a "Canadian" literature?

We've tried very hard over the past few decades to demonstrate our own existence, our own right to exist. Usually we ourselves - the writers, that is - don't doubt it; the voices of denial come from elsewhere. But this may explain, a little anyway, the concern with "theme." One can only afford "a thoughtful consideration of technique" when the question of mere existence is no longer a question.

J.C.O.: What are you working on at the present time?

M.A.: I have two novels in my head, and I hope to start one of them this summer, but I can never talk about a book in advance. They always change so much. Right now, I have a volume of poems which is at the editing stage. The title is Two-Headed Poems and Others, and it will be out, I think, with Oxford in Canada in the fall. I'm also working on some stories, which I hope to include in the American edition of Dancing Girls.

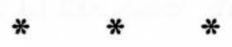


Margaret Atwood was born in 1939 in Ottawa, though her parents are both from Nova Scotia and her "extended" family lives there, and grew up in and out of Ottawa, Sault Ste. Marie, Toronto, and the Québec bush. She studied at Victoria College, University of Toronto, where she received her B.A. in 1961, and at Harvard, where she received her M.A. in 1962. She was a lecturer in English at the University of British Columbia and at Sir George Williams University in Montreal. She has received numerous awards, among them the Governor General's Award for Poetry in 1966. At the present time she lives with her husband, Graeme Gibson and their infant daughter on a farm in Alliston, Ontario, 65 miles north of Toronto. Her books are:

Poetry:

The Circle Game

The Animals in That Country

The Journals of Susanna Moodie

Procedures for Underground

Power Politics

You Are Happy

Selected Poems
Fiction:

The Edible Woman

Surfacing

Lady Oracle

Dancing Girls (stories)

Criticism:

Survival: A Thematic Guide to Canadian Literature

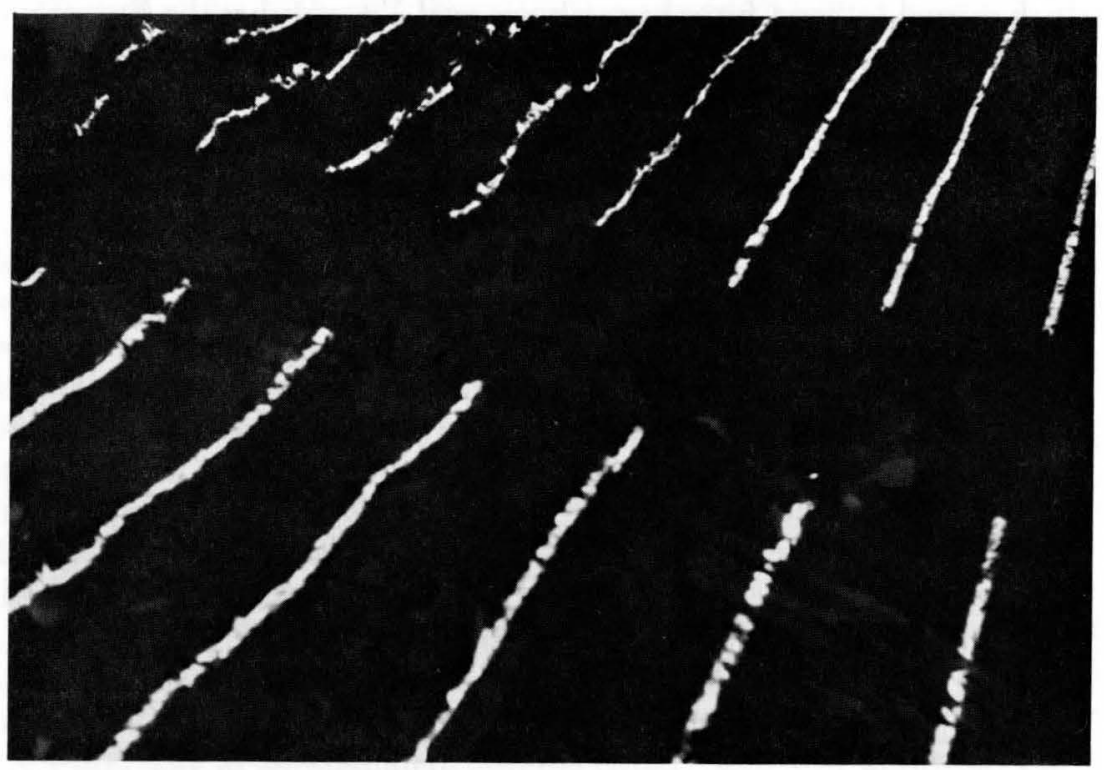

Bela Egyedi 